\title{
What is Restorative Justice? Fresh Answers to a Vexed Question
}

Professor Kathleen Daly

School of Criminology and Criminal Justice

Mt Gravatt Campus

Griffith University QLD 4111

AUSTRALIA

ph: $+61(0) 73735-5625$

email: k.daly@griffith.edu.au

www.griffith.edu.au/professional-page/professor-kathleen-daly

Prepared for Victims \& Offenders, special issue, Does Restorative Justice Have a Future? revised 9 October 2015

My thanks and appreciation to Susanne Karstedt, Robyn Holder, and William Wood for their comments on an earlier draft. 
What is Restorative Justice?

Fresh Answers to a Vexed Question

\begin{abstract}
It has become commonplace to say that restorative justice cannot be defined. I argue that restorative justice can and must be defined concretely as a justice mechanism. I develop this argument with four points: (1) restorative justice is not a type of justice; it is a justice mechanism; (2) retributive justice is not a type of justice or a justice mechanism; (3) restorative justice is one of many justice mechanisms under an innovative justice umbrella; and (4) restorative justice can be defined. The way forward is to assess and compare a variety of justice mechanisms, which reside on a continuum from conventional to innovative. In time, the justice mechanisms studied may come to matter more than the concept of restorative justice.
\end{abstract}

Keywords: restorative justice, retributive justice, conventional and innovative justice, justice mechanisms

Running head: What is restorative justice? 


\section{INTRODUCTION}

This paper addresses a problem for restorative justice researchers and practitioners: how do we answer the question, what is restorative justice? ${ }^{1}$ Is it a theory of justice? A new way of thinking about crime and justice? A set of values that should guide justice practices? A popular term for government, church, and community people? All of these? Or something else?

A recent example of the problem appears in Volume 1 of European Research on Restorative Juvenile Justice, where the authors say:

There is ... no clear cut definition of what $\mathrm{RJ}$ actually is. ... RJ ... has come to be used to describe processes and practices that seek to employ a different approach to resolving conflicts. RJ regards the criminal justice system as an inappropriate forum for resolving criminal offences ... (Dünkel, Horsfield, \& Păroşanu, 2015a, p. 4)

When confronted with the question [of] what RJ actually is, a frequent response [is] it "means different things to different people" or "all things to all people" [citations to Fattah, 1998, p. 393; O’Mahony \& Doak, 2009, p. 167, respectively]. Van Ness and Strong (2010, p. 41) state that "it can seem that there are as many answers as people asked." There is no clear-cut definition of what RJ is, not least because [according to Van Ness and Strong, 2010], "it is a complex idea, the meaning of which continues to evolve with new discoveries ..." (Dünkel, Grzyna-Holten, Horsfield, \& Păroşanu, 2015b, p. 177)

The flexibility (or room for personal preference) in defining the concept "has led to a raft of divergent practices and lack of consensus on how they should be implemented" [citation to Doak \& O’Mahony, 2011, p. 1718).... What has become clear, however, 
is that the outcomes achieved through restorative practices have indeed been very promising ones ... (Dünkel et al., 2015b, p. 180)

We learn several things from these passages. First, restorative justice is an "actor" (not merely a justice practice), endowed with thoughts and views, such as not regarding the criminal justice system to be an appropriate place to respond to crime. ${ }^{2}$ Second, RJ (as a justice practice) cannot be defined, in part because individuals may choose to define it as they wish, and in part because it is a complex and evolving concept. Third, despite no "clear-cut definition," outcomes are "very promising." Whatever could this mean? Put another way: over two decades of research on restorative justice show apparently "promising" outcomes for a justice activity that cannot be defined.

Definitions of restorative justice vary along several axes. Some focus on types of processes (typically face-to-face meetings); others center on outcomes (e.g., any action that "repairs the harm caused by crime" [Bazemore \& Walgrave, 1999, p. 47-48]); and still others combine process and outcome (Van Ness \& Strong, 2006, p. 43). An aspirational trajectory emphasizes societal and individual transformation (see Johnstone \& Van Ness, 2007, for three conceptions of RJ).

The varied ways that people define and use the term restorative justice can be explained, in part, by their "voyage", with it—as advocates, researchers, government officials, members of community and faith-based organizations, among many others. Although the modern use of the term began to take hold in affluent nations in the early 1990s, it has become increasingly popular in emerging developed countries. Here I note that a common, if erroneous, claim is that restorative justice can be traced to ancient or Indigenous justice practices and was the dominant form of pre-modern justice. This origin myth romanticizes the past and does not accord with evidence (see Bottoms, 2003; Daly, 2002b; Pratt, 2006). ${ }^{4}$ 
My paper advances four points about RJ as a concept and subject of theoretical and empirical inquiry. To the question posed by this special issue, does restorative justice have a future?, I argue that it may, at least in the near term, if it is defined concretely as a justice mechanism. Its future is in doubt if its scope is larger than this. Restorative justice must be defined concretely because its practices and outcomes must be subject to empirical inquiry. Values and principles have relevance; however, they need to be anchored in an understanding of restorative justice as a justice mechanism, not an alternative to retributive justice, not a new way of thinking about crime and justice, and not a set of aspirations for social change.

\section{PROBLEMS OF DEFINING RESTORATIVE JUSTICE}

\section{Popularity and diversity}

Those familiar with restorative justice, as researchers and practitioners, have a settled idea of what it is. The definitional problem is aggregating all the individual understandings into a coherent whole. This is not possible because researchers and practitioners often have:

(1) different views about what is (or is not) restorative justice and its associated practices; and

(2) a geographically limited understanding of what is occurring: we can speak authoritatively about our own country or others nearby, but beyond this, knowledge can be limited.

In addition,

(3) There is significant variation over time in a jurisdiction's practices. Funding for certain initiatives may be increased, decreased, or cut altogether. Hybrid practices emerge that are based partly on RJ and partly on other justice activities.

(4) The term "restorative" is applied to many activities or outcomes in criminal justice, which are only distantly related to it. For example, "restorative sanctions" is used to 
refer to non-custodial penalties. "Restorative" is used to describe any activity that is not concerned with prosecution or conviction, or more broadly, that does not intend to be adversarial, punitive, or a type of punishment.

(5) Restorative justice practices are used in non-criminal justice matters, such as child protection, as well as disputes or conflict in schools and other settings.

(6) The popularity of the idea has affected a broad range of humanities and social science disciplines (including law, linguistics, politics, psychology, sociology, philosophy, religious studies, international relations, as well as criminology and criminal justice). Thus, analysis of definitions, practices, and effects take different forms, depending on an analyst's disciplinary field and research interest.

\section{Restorative justice as a "contested concept"}

Drawing from Gallie's (1956) influential essay, Johnstone and Van Ness (2007, p. 6) argue that RJ is "not simply a persistently vague concept, it is in fact a deeply contested concept" (emphasis in original). They offer three reasons: RJ is an "appraisive concept" (it is used to evaluate a justice activity); it is "an internally complex concept" (it contains varied elements, not all of which may feature in a justice activity); and it is "an open concept" (it has shifted in meaning over time to include wider aspirations and activities). ${ }^{5}$ It is precisely the openness and wider understandings of the concept, which I argue, have led to problems of defining it.

Johnstone's (2008) identification of five agendas of the RJ movement shows how the term has become increasingly large in scope and application. Agenda one, the most familiar, is concerned with changing social responses to crime. This agenda marked the start of RJ as a justice activity applied mainly to youth crime. Agenda two is concerned with the ways in which "crime" and "a good solution" to it are defined (Johnstone, 2008, p. 64) and is 
exemplified in the ideas of Zehr $(1985,1990)$. This agenda shifts attention away from actual practices to new ways of thinking about crime and justice. Crime is a violation of a person (not only an offense against the state), and a good solution is "repairing the harm and healing ${ }^{6}$ the trauma caused by crime" (Johnstone, 2008, p. 67). Agenda three extends RJ practices to other organizational sites such as schools and workplaces, and to community conflicts. Within organizational settings, "restorative processes ... [are] a tool that can be used to manage people more effectively ... to achieve the ... goals of an organization" (Johnstone, 2008, p. 68). For community conflicts, "restorative dialogues" have been used to respond to hate crime (Coates, Umbreit, \& Vos, 2006); and "community restorative justice," to sectarian violence in Northern Ireland (McEvoy \& Mika, 2002).

Agenda four extends RJ to "projects of political reconciliation" (Johnstone, 2008, p. 69) in responding to the legacy of slavery in the U.S., and to mass violence, state violence, and genocide in war-torn regions and repressive states in Europe, Africa, South America, and Asia. Here we see the spread and cross-fertilization of RJ ideas with those in international and transitional justice. As I shall show, many justice mechanisms are used in transitional settings and have been subject to empirical inquiry; however, it is inaccurate to call them restorative justice. Agenda five uses a transformative concept of RJ. It is exemplified by Braithwaite (2003, p. 1), who says that RJ is not just about "reforming the criminal justice system, [but] a way of transforming our entire legal system, our family lives, our conduct in the workplace, our practice of politics.” Walgrave (1995, p. 245) suggests that RJ is “... an ideal of justice in an ideal of society, [which depends on] ... a change in social ethics and a different ideology of society." Thus, RJ is viewed both as a catalyst for social change (Braithwaite) and an ideal of justice (Walgrave).

Agendas one and three are concerned with justice practices, that is, concrete activities that can be subject to empirical inquiry. Agenda four includes concrete activities that are 
subject to empirical study (for example, truth commissions), but these are transitional justice or truth-seeking mechanisms, and should not be called restorative justice. Agenda four analysts also use RJ to refer to anything that is not "retributive justice" or that aims "to rebuild broken relationships and communities" or that has "reconciliation" as the goal (Porter, 2012, pp. 233-234). Thus, in this respect, agenda four is like agendas two and five in not having a specific empirical focus; rather, the emphasis is on ways of thinking about crime, justice, and social transformation. These latter agendas are responsible for the inability to define RJ today.

Why is it important to define restorative justice? And is the inability to define it fatal? Johnstone and Van Ness (2007, p. 19) do not believe it is fatal. They believe that varied conceptions of RJ reflect "the richness of the concept" and may provide "new insights about how to apply restorative measures to make things better than they are now." Writing at about the same time as Johnstone and Van Ness (2007), I too said that the inability to define RJ was not fatal, but reflected a diversity of interests and ideologies that people bring to the table when discussing ideas of justice (Daly, 2006, p. 135). I have since changed my mind. My reasoning is that the research and development phase of restorative justice has now past, and it is time to assemble evidence, using a range of methods. ${ }^{7}$ Without a definition of RJ that can be applied and assessed empirically, we are bobbling on a raft in a sea of hopes and dreams.

\section{MY VOYAGE WITH RESTORATIVE JUSTICE}

I have come to understand RJ in a particular way, one that I think is preferable to others circulating today. My understanding has evolved over many years of conducting research on RJ, beginning in the early 1990s. My story started even earlier, in the late 1980s, when I was embarking on a longstanding intellectual and political interest: to address the race and gender politics of justice. By this I mean working with two problems for crime and justice 
simultaneously: over-criminalizing socially and economically marginalized individuals, often members of political minorities; and at the same time, finding better ways to address gender violence. ${ }^{8}$ I was troubled by a (then) dominant feminist focus on victims in the criminal process, to the exclusion of offenders (Daly, 1989).

These concerns came to a head in May 1992, when I spoke at a plenary panel at the Law \& Society conference on the Clarence Thomas confirmation hearings. Thomas, a black man, was nominated to the United States Supreme Court in 1991. During the U.S. Senate's hearings in October, a law professor and black woman, Anita Hill, testified that Thomas sexually harassed her over a period of time in the 1980s, when he was Chair of the Equal Employment and Opportunities Commission and she worked in the office. Thomas denied Hill's allegations as groundless. Critics accused Hill of being disloyal to her race, of trying to bring down a black man. In my plenary address, I asked:

If Thomas admitted he harassed Hill, and if he admitted this in ways you found sincere, and if he apologized for what he did and said he would make amends, what would have been your response? Would his admissions, apology, and efforts to make amends have been sufficient ... or would you want more of a sanction? (Daly, 1992, p. 4)

My remarks caused some controversy. I appeared to have broken with feminist convention, which at the time was concerned with strengthening formal legal approaches to violence against women, not identifying alternative justice practices.

John Braithwaite was in the audience. Less than a year later, in February 1993, he sent me a draft paper on "family group conferencing" in Wagga Wagga, New South Wales. It suggested that conferencing (which would later be branded restorative justice) could challenge violent masculinities and bring forward feminist voices. I recall vividly my 
excitement reading the paper. We went on to co-author it (Braithwaite \& Daly, 1994), and it was the start of my travels to Australia.

In 1995, I relocated from the U.S. to Australia to carry out research on restorative justice. Within weeks of arriving in Canberra, I travelled to South Australia, which was the first Australian jurisdiction to legislatively establish youth justice conferences with the Young Offenders Act 1993. In another visit about a month later, I participated in an all-day meeting with the conference coordinators. Butcher block paper was put up on the walls, and our task was to answer the question, "What is restorative justice?" We all found the task difficult, and in particular, we were unsure of how RJ related to a well-known practice, family group conferences.

Over the next 4 years, I observed many conferences and interviewed many victims and youth offenders. What I learned from my research did not square with what RJ advocates were saying. That, coupled with the butcher block paper exercise, leads me to points 1 and 2 of my argument.

\section{THE ARGUMENT IN FOUR POINTS}

I shall elaborate upon these points:

- Point 1: Restorative justice is not a type of justice. It is a justice mechanism.

- Point 2: Retributive justice is not a type of justice or a justice mechanism.

- Point 3: Restorative justice is one of many justice mechanisms under an innovative justice umbrella.

- Point 4: Restorative justice can be defined.

\section{Points 1 and 2}

To develop points 1 and 2, I consider domestic contexts of criminal justice ${ }^{9}$ and then transitional justice contexts. 
Domestic criminal justice contexts

The binary that Zehr introduced in 1985 of the "old and new paradigms of retributive and restorative justice" had a pleasing ring, but it has created significant conceptual confusion. Specifically, it spawned the view that there were two types of justice: the "retributive" and the "restorative." I have long been critical of this contrast, with measured and careful critiques (see Daly and Immarigeon 1998; Daly, 2000, 2002a, 2002b for early examples). However, the contrast continues to be used in textbooks and scholarly papers, and has become a dominant trope to compare two types of justice.

Thus, it is time for me to escalate by making a clear and bold statement. And it is this: the juxtaposition of "retributive and restorative justice" is a nonsense. Its use should cease for two reasons. First, retributive justice, as a coherent system or type of justice, does not exist. What people are referring to, in fact, is conventional criminal justice, which has many aims and purposes, some of which are contradictory. Retribution is just one aim. Others are rehabilitation, general and special deterrence, and incapacitation. The standard mechanisms of conventional criminal justice are criminal prosecution, adjudication and trial, and sentencing; but others include victim impact statements. To call the whole set of practices and outcomes of conventional criminal justice "retributive" or "retributive justice" (or "punitive justice" as some also say) is also a nonsense because many cases reported to the police do not result in arrest or prosecution.

Second, restorative justice, as a coherent system or type of justice, does not exist. Any comparison of conventional criminal justice mechanisms with other mechanisms, such as RJ, must acknowledge that the latter is concerned with justice practices only after a person has admitted to an offense. Thus, despite what advocates may wish to believe, RJ cannot 
replace conventional criminal justice because it lacks a method of fact-finding — an important, although often overlooked, fact.

When the idea of RJ first emerged in domestic criminal justice, the juxtaposition of retributive and restorative justice served as an "elegant and catchy exposition" (Roche, 2007, p. 87). Since then, well-known RJ advocates, including Van Ness and Strong (2006), Walgrave (2004), and Zehr (2002), have conceded that the better contrast is between conventional criminal justice and restorative justice, and that retribution does have a place in RJ practices. Despite their concession, the idea that there are two types of justice continues in the domestic criminal justice literature, and it has become entrenched in the international and transitional justice literature.

\section{Transitional justice contexts}

The movement of the retributive-restorative contrast into transitional justice settings ${ }^{10}$ can be traced to how Archbishop Desmond Tutu framed the establishment of South Africa's Truth and Reconciliation Commission (TRC) in 1995. Tutu embraced the idea of restorative justice: he believed it was similar to traditional African jurisprudence (Ubuntu) and reconciliation. In the 1995 TRC legislation, a contrast was drawn between restorative justice and vengeance, the latter associated with retributive justice. Here, we see two layers of binary opposition: between restorative ("African") and vengeance-defined retributive ("Western") justice (Roche, 2007, p. 78).

An early and influential analysis of South Africa’s TRC by Minow (1998, p. 91) reinforced the contrast. She said that the TRC "moved away from prosecutions toward an ideal of restorative justice ... The TRC emphasizes truth telling, public acknowledgment, and reparations ..." unlike "retributive approaches, which may reinforce anger and a sense of victimhood." Thus, in the South African TRC, avoiding "retributive approaches" (defined as not using criminal prosecution) was called restorative justice. Although TRC proponents 
claimed to be using restorative justice principles by not engaging in mass prosecutions and by granting amnesties, most truth commissions do not operate this way (Hayner, 2011, pp. 104105). Despite such variation, the legacy of South Africa's TRC is that truth commissions are viewed as a "restorative justice approach" in the transitional justice literature (Brahm, 2007, p. 19). ${ }^{11}$ More accurately, they are a "truth telling" or "truth seeking" justice mechanism. In addition to South Africa's TRC, there is a second reason that the retributiverestorative contrast has taken hold. Section VII of the UN General Assembly's Resolution on Basic Principles and Guidelines on the Right to a Remedy and Reparation (2006) identifies three rights of victims to pursue violations of international human rights and international humanitarian law: “... access to justice [criminal, civil, and administrative], ... reparation for the harm suffered, [and] access to relevant information on violations and reparations mechanisms" (UN General Assembly, 2006, A/RES/60/147, p. 6). Simplifying greatly, in the UN and developing jurisprudence of national and international human rights bodies, "reparation" for victims is distinguished from "justice." RJ-associated activities (some of which would fall under the reparation component) may run parallel to justice activities, but are not constitutive of them.

By contrast, in domestic criminal justice contexts, RJ advocates, especially those taking an outcome definition of RJ, define "justice" as "reparation." In other words, the two are dissolved: one is constitutive of the other. In these contexts, advocates suggest that we choose reparative (or restorative) justice over retributive justice (see Daly \& Proietti-Scifoni, 2011). Despite differences in having to choose between restorative and retributive justice (in domestic contexts) or in viewing them as separate entities (in transitional contexts), the literatures in each frame retributive and restorative justice in a similar way: as two types of justice. Depending on the author and context, these may be understood as oppositional or complementary. 
The transitional justice literature opened my eyes to another way to call the range of responses to crime, civil war, state violence, and mass atrocity. These should be called "justice mechanisms," which leads to my third point.

\section{Point 3: Restorative justice is one of many justice mechanisms under the innovative justice umbrella}

This point has two linked claims. First, RJ is a justice mechanism (part of point 1); and second, the umbrella term for a number of such mechanisms is innovative justice, not restorative justice. To elaborate, I return briefly to my voyage with new justice practices.

\section{Continuing the voyage}

In 2001, I began to study contemporary forms of Indigenous justice in South Australia, Queensland, New South Wales, and the ACT. These practices do not rely on customary law, but are sentencing activities that take place typically (although not exclusively) in magistrates' or local courts. Specific practices vary by jurisdiction, but in general, they are more informal and use a more culturally appropriate process with the participation of Elders and Respected Persons (Daly \& Marchetti, 2012).

This research was crucial to my re-thinking the concept of restorative justice.

Although there are some shared elements of restorative justice and Indigenous sentencing courts, the justice aims and political aspirations of Indigenous courts put them in a different category. In addition to a more culturally appropriate process, the aim is to engender greater trust between "white justice" and Indigenous communities, and the political aspiration is to change race relations between "white justice" and Indigenous communities (Marchetti \& Daly, 2007). Despite this, some depict Indigenous sentencing courts as an example of restorative justice (e.g., Weatherburn, 2014, pp. 99-101). This occurs, I believe, when analysts have not observed the practices, talked with those on the ground, or absorbed the relevant literature. 
Moreover, depending on context and jurisdiction, certain practices such as circles are aligned with RJ, whereas other circle practices are aligned with Indigenous sentencing courts. ${ }^{12}$ With such variety, it may be easy to say or to assume that all such practices fall into the same basket of alternatives to conventional criminal justice, and further, that there is one name for that basket, restorative justice. This is a significant problem for the field. Analysts need to recognize that a variety of justice mechanisms exists, which do not have the same aims and processes.

\section{What is a justice mechanism?}

A justice mechanism is a justice response, process, activity, measure, or practice - all of these terms could be used interchangeably. Justice mechanism is the term of choice in the transitional justice literature, when researchers study and assess varied justice mechanisms that have been used in transitions from repressive state regimes and civil war toward more democratic rule and peace. Drawing from Backer (2009, Appendix Table A2.1) and Olsen, Payne, \& Reiter (2010, p. 31), these include criminal prosecution; lustration, bans, and purges; reparations (financial, employment, symbolic); investigations (truth commissions or independent inquiries); institutional reform; immunity (amnesties and pardons); and memory projects. Some mechanisms, such as reparations, may be individual or collective. The value of the term justice mechanism, as developed in the transitional justice literature, is that it identifies the distinct and multiple mechanisms that are (and have been) used by countries in transition. Researchers have sought to identify the mix of mechanisms (and their timing) to determine what is effective, using a cross-national comparative method.

Empirical research on mechanisms in domestic contexts of criminal or civil justice, or in organizational and community settings, can benefit from this method of assessing and comparing justice mechanisms; and when possible, to use a cross-national comparative method. For simplicity here, I focus on domestic contexts of criminal justice, but it is important to also have in mind civil and administrative justice. I propose that we see justice mechanisms as 
residing on a continuum from conventional to innovative. These are umbrella terms that hold a variety of justice mechanisms. They are not types of justice, nor are they mutually exclusive. In other words, differing mechanisms (conventional and innovative) can be used in one case (Daly, 2011, 2014).

Conventional mechanisms refer to standard approaches to criminal prosecution, trial, sentencing, and post-sentence; they also include advocacy for victims (e.g., victim lawyers) and modes of victim participation (e.g., victim impact statements). Specialist courts for domestic or sexual violence may be conventional or a conventional-innovative hybrid, depending upon how they operate. ${ }^{13}$

Innovative mechanisms do not rely solely on the standard tool kit of criminal procedure or justice practices, or those wedded to legal processes alone. They permit greater participation and interaction of the relevant parties. The processes are often more informal, although structured by rules and procedures. $\mathrm{RJ}$ is one of many justice mechanisms under the innovative justice umbrella. Others are problem-oriented courts (although these are often closer to conventional mechanisms), contemporary Indigenous justice practices, circles of support and accountability, a variety of informal (non-state) justice mechanisms, people's tribunals, truth telling or truth seeking mechanisms, cultural performances, days of remembrance, and other art and activist projects in civil society. Innovative justice mechanisms may work alongside or be integrated with conventional criminal justice or operate in civil society. When part of criminal justice, the process is set in motion only after admissions to offending. ${ }^{14}$

\section{Why innovative justice is a better umbrella term}

The term innovative justice solved two problems for me: the conceptual expansion of restorative justice and feminist critiques of restorative justice. 


\section{The problem of conceptual expansion.}

With the popularity and conceptual expansion of restorative justice, the term began to be associated with a range of activities and practices. A review essay by Menkel-Meadow (2007) is illustrative. She uses restorative justice as an umbrella concept to refer not only to mediated meetings of victims and admitted offenders (and their supporters and others), but also to contemporary Indigenous justice practices and problem-solving courts, such as drug courts, and then, to transitional justice mechanisms.

For domestic contexts of criminal justice, Menkel-Meadow merges restorative justice with Indigenous sentencing practices and problem-solving courts. She cites reports from Canada (Stuart, 2001) and the U.S. (Yazzi \& Zion, 1996) on modern forms of Indigenous sentencing practices. She views these as sparking interest in "a more flexible, tailored, and communitarian sense of justice or fairness," with "the greatest ... impact ... in New Zealand, where family conferencing modelled on both traditional Maori and modern practices developed into a mandatory model for juvenile justice" (Menkel-Meadow 2007, pp. 167-168). ${ }^{15}$ She then suggests that in the U.S., "a new development [is] 'problem-solving courts' in which restorative and rehabilitative principles have made their way into the formal justice system as specialized courts [for] drug offenses, vice, abuse, neglect ..." (p. 168). Thus, problem-solving courts (which, in fact, draw from therapeutic jurisprudence) and restorative justice are merged. Later, she terms problem-solving courts "specialized reparative courts" (p. 177), a startling claim, because reparation is not an aim or purpose of problem-solving courts.

One problem with Menkel-Meadow's depiction of the evolution of restorative justice is that there were parallel streams of activism and new justice practices from the 1960s to the 1990s in North America and elsewhere. Conflict resolution, victim-offender mediation, informal justice, family group conferencing, among many others, evolved from different groups of activists, practitioners, and academics (often unknown to each other), who were 
experimenting with new justice ideas (Daly and Immarigeon, 1998, pp. 23-29). Restorative justice, as an animating idea, did not take hold until the early 1990s. My aim is not to write a definitive history of restorative justice as a source of advocacy, legislation, and policy in the many countries in which the term has assumed prominence. Rather, it is to point out that analysts tend to simplify what is a fragmented and parallel set of justice developments, which germinated in social movements of the 1960s and then grew and hybridized over the next four decades into a variety of justice activities. These had (and have) different aims and purposes, and it would be inaccurate to call them all "restorative justice."

For transitional contexts, Menkel-Meadow (2007, p. 164) argues that restorative justice principles "helped form a new field of international law and political structure: transitional justice." Here, she traces the movement of RJ in domestic contexts of criminal justice to its explicit incorporation in South Africa's TRC. From here, she suggests that statemodified indigenous practices in post-conflict societies (e.g., gacaca courts in Rwanda) reflected "newly minted restorative processes," which expanded further to " 25 national efforts to move more peacefully" into post-authoritarian and post-conflict states. Transitional justice scholars would be astonished to read this history of transitional justice, and in particular, the story of steady progress from authoritarian rule and civil war to peace, and the starring role played by restorative justice. ${ }^{16}$

In sum, diverse justice mechanisms, with multiple aims and purposes, are placed in the one basket of restorative justice. How did this come to be? The answer, in part, lies in how analysts have come to define restorative justice: "more of an idea, philosophy, set of values, or sensibility than a single and uniform set of practices of processes" (Menkel-Meadow, 2007, p. 179), and in part, how the story of its evolution is told. Menkel-Meadow (2007) suggests that restorative justice "began as an idea to reduce the punitive nature of conventional criminal punishment ... and to improve criminal justice," but then expanded "into a social and political 
movement seeking to use restorative or reparative sensibilities to heal not only single acts of misconduct, but [also] civil wars, genocides, and international ... conflict" (pp. 179-80). With such an open-ended frame of reference - to reduce punitivism, improve criminal justice, and use restorative sensibilities — anything is possible. ${ }^{17}$

Feminist critiques of restorative justice.

As the concept of restorative justice grew in popularity, debate emerged about its appropriateness for partner, sexual, and family violence. A considerable scholarship began to emerge (for early edited collections, see Cook, Daly, \& Stubbs, 2006; Ptacek 2005, 2010; Strang \& Braithwaite, 2002). I have been researching conventional and innovative justice responses to gender violence since 2000 . Over time, I have come to see the value of conferences as a justice mechanism, but I am also sympathetic to feminist critiques of restorative justice, in particular, off-the-shelf RJ practices require major revision, if they are to be victim-focused and appropriate for cases of gender violence.

The term "restorative" poses significant problems for feminist critics. For example, many suggest that "restoring" relationships (especially those marked by violence) may not be desirable (e.g., Acorn, 2004). In reply, I said that restorative justice should not be interpreted literally to mean restoring people or relationships. Rather, it is a nominal concept that stands for a set of activities, which are typically meetings between admitted offenders, victims, and relevant others ${ }^{18}$ in response to wrongs, disputes, or bounded forms of community conflict. I reasoned that the term innovative justice, defined as an umbrella concept and not as a type of justice, could address critics' concerns that expected outcomes could only (or mainly) be "restoration" or "reconciliation."

\section{Point 4: Restorative justice can be defined}

My definition of restorative justice, as a justice mechanism, will not be controversial to those who view RJ as an activity, not an idea, philosophy, or way of thinking about crime 
and justice. My definition is closer to the "purist" (or process) definition (McCold, 2000, p. 401) compared to a "maximalist" (outcome) definition that centres on repairing the harm (Walgrave, 2000, p. 418). My definition will not be controversial to those who view a variety of informal (non-state) justice mechanisms, particularly those used in the developing world, as distinct from the modern concept of restorative justice. However, my definition will be controversial to those who view an ever-increasing inclusion of diverse justice practices in domestic and transitional contexts as a positive development, that is, of the growing scope and diversity of "restorative justice." It will also be controversial to those who imagine restorative justice to be anything that is not a conventional criminal justice mechanism or that is "not punitive."

Here is my definition:

Restorative justice is a contemporary justice mechanism to address crime, disputes, and bounded community conflict. The mechanism is a meeting (or several meetings) of affected individuals, facilitated by one or more impartial people. Meetings can take place at all phases of the criminal process, pre-arrest, diversion from court, pre-sentence, and postsentence, as well as for offending or conflicts not reported to the police. Specific practices will vary, depending on context, but are guided by rules and procedures that align with what is appropriate in the context of the crime, dispute, or bounded conflict.

To highlight and clarify several elements of my definition:

- I say "bounded community conflict" to exclude civil war, state violence, and wider socio-political conflicts and cleavages, for which other justice mechanisms are appropriate.

- As a justice mechanism, restorative justice is a meeting (or set of meetings) of people.

- A meeting assumes an encounter or process conception of restorative justice, not an outcome conception, because desired outcomes will vary by the context and purpose of 
the meeting. In other words, outcomes should not be restricted to repairing harms or restoring relationships.

- $\mathrm{RJ}$ is a contemporary justice mechanism, not pre-modern or customary practice, and not a therapeutic mechanism, although it may have therapeutic effects.

Shapland argues (2014, pp. 122-23) that there needs to be an "explicit recognition" of differing "restorative justice processes in different contexts.” I concur, but I would not bound RJ processes by values (as Shapland suggests we do), but rather by rules and procedures that should govern any lawful justice mechanism. RJ scholars have produced different lists of values or principles, itself a topic for analysis, but one that is beyond the scope of this paper.

The bright line that demarcates my definition of restorative justice from others is that justice mechanisms, such as "conferences" and "community dialogues," can be empirically studied and compared with other mechanisms. I am currently conducting research along these lines, which compares two justice mechanisms, conferences and criminal sentencing, in responding to cases of sibling sexual violence. I analyze the actual workings of these mechanisms, using as the evaluative criteria, the degree to which they achieve "victims' justice interests" for participation, voice, validation, vindication, and offender accountability (Daly, 2014; Daly and Wade, 2016). Of course, other evaluative criteria can be identified, depending on the purpose and focus of investigation. My point is that research needs to record and assess the actual workings and effects of justice mechanisms, and not solely with reference to participants' "satisfaction" or measures of re-offending. By taking this research tack, we may build useful knowledge on the strengths and limits of conventional and innovative justice mechanisms, used alone or in combination.

\section{Summary and conclusion}

To summarise, the definitional problems of restorative justice can be attributed to: 
- Depicting RJ as a type of justice in contrast to conventional criminal justice, which is wrongly called "retributive justice."

- A conceptual expansion of RJ to include all types of justice activities that are not modern forms of conventional criminal justice, or are new ways of thinking about crime and justice, or have aspirations for social and individual transformation.

- The popularity of restorative justice as a term, with many activities or outcomes branded "restorative," which bear little relationship to meetings, as described above.

- The selective take up of RJ from domestic contexts of criminal justice in affluent nations at peace to post-conflict transitional settings, where the retributive-restorative contrast is reinforced. ${ }^{19}$

As a concept, restorative justice has become too capacious and imprecise. If it cannot be defined, it cannot be subject to empirical and theoretical study. However, if restorative justice is conceived as a contemporary justice mechanism, as outlined in my definition, relevant justice activities can be subject to empirical inquiry and theorization. In time, the justice mechanisms studied may come to matter more than the concept of restorative justice.

\footnotetext{
${ }^{1}$ Throughout this paper, I use restorative justice and RJ interchangeably, or in the case of the quoted material here, what the authors said.

${ }^{2}$ Characterizing restorative justice as an "actor" — and not a justice activity_occurs frequently. When doing so, analysts suggest that restorative justice is a field of knowledge, with limits and challenges. Imagine if we changed the sentence to say "conventional criminal justice regards justice alternatives as not appropriate in responding to crime." That would sound odd.

${ }^{3}$ I first presented these ideas in a plenary address to the British Society of Criminology in July 2015, where "critical voyages of discovery" was the conference theme. I thank the conference organisers for inviting me to consider my critical voyage with restorative justice.
} 
${ }^{4}$ Johnstone (2011, pp. 40-41) suggests that my argument that RJ advocates have re-written history to authorize restorative justice as the first human justice is "somewhat harsh" because "there was once a mode of life in which some part of the law belonged to the community." My point is that known histories of justice practices do not conform to the origin myth of RJ. Having said that, some RJ practitioners do utilize selected aspects of North American Indigenous worldviews as the values base for their activities, such as peacemaking circles (see, e.g., Pranis, 2015).

5 Johnstone and Van Ness (2007, p. 20, end note 2) say their analysis is "influenced" by Gallie's (1956) essay on "Essentially contested concepts," but one would have wished they had used quotation marks when using Gallie's own words. Gallie (1956, pp. 171-172) identified five elements: "appraisive, ... internally complex, initially describable, open," and a recognition that the concept is contested by others. Gallie also notes that "any contested concept is persistently vague" (p. 172, emphasis in original). My thanks to Susanne Karstedt for calling my attention to Gallie's original essay.

${ }^{6}$ The term "healing" blends Aboriginal or Indigenous spirituality with Christian principles and general therapeutic aims, and is commonly used by restorative justice advocates. While respecting other belief systems (in particular, the relevance of healing to First Nations and First Peoples), my view is that healing should not be an explicit goal of justice activities for two reasons: its strongly Christian religious overtones and its focus on positive states of mind as the principle aim of justice activities.

${ }^{7}$ There are, of course, systematic reviews of random controlled trials of restorative justice conferencing practices (Livingstone, Macdonald, \& Carr, 2013; Strang, Sherman, MayoWilson, Woods, \& Ariel, 2013). This is one method of assessing and comparing differing justice mechanisms, but it is not the only one. Certain offenses, such as sexual assault, are not included in systematic reviews and require other methods of assessment. Moreover, it is 
essential that results from randomized controlled trials pay attention to the context of conferencing practices. For example, victims' experiences of a supplemental pre-sentence conference, when offenders are being held in custody, can be expected to differ from victims' experiences of youth diversionary conferences. This contextual difference is ignored by Sherman et al. (2005) (see critique in Daly, 2014, p. 391, endnote 14).

${ }^{8}$ There are, of course, other relevant social relations (of class, age, sexualities); here I have in mind the overlay of offender- and victim-centered conceptions of justice with race and gender politics, respectively.

${ }^{9} \mathrm{RJ}$ practices are used in other than criminal justice contexts, but I use this context to make comparisons.

${ }^{10}$ Transitional justice is not a type of justice. Rather, Ruti Teitel coined the term in 1991 to refer to "a distinctive conception of justice associated with periods of radical political change following past oppressive rule" (Teitel, 2008, p. 1). Today, the term refers to a vast globalized field of interdisciplinary scholarship and activism. A simple definition is the steps taken to address a country's history of state repression and violence, civil war, or ethnic/religious conflict in moving toward peace and democracy.

${ }^{11}$ In addition to not using criminal prosecution, Brahm (2007, p. 19) says that a restorative justice approach means to "build community ... by emphasizing reconciliation ... and by focusing on the underlying causes of conflict and human rights abuses ... rather than on individual perpetrators."

${ }^{12}$ An example of the former is circles in Michigan as a restorative justice practice (Pranis, 2015), and of the latter, circles in New South Wales as an Indigenous sentencing court practice (Daly and Proietti-Scifoni, 2009).

${ }^{13}$ Another conventional mechanism that may be innovative or a hybrid, depending on actual practices, is victim advocacy. My thanks to Robyn Holder for clarifying this point. I do not 
wish the terms "conventional" and "innovative" justice to suffer the same fate as "retributive" and "restorative justice" with the inference drawn that one is the "bad" and the "good" justice, respectively. The two terms are less important than the actual workings of the justice mechanisms themselves in context.

${ }^{14}$ Even for community referrals to adult conferences for sexual violence (as compared to court referrals), acknowledgment of offending is a prerequisite to a meeting (Jülich, Buttle, Cummins, \& Freeborn, 2010, p. 75).

${ }^{15}$ Menkel-Meadow also notes the role of conservative and Christian pro-family advocacy groups in promoting the idea.

${ }^{16}$ Transitional justice scholars would trace the history of the field as beginning with the Nuremberg trials. Teitel (2003) identifies three phases of transitional justice in the decades following World War II: an international law focus on accountability, a restorative model, and a steady-state model. She characterizes the restorative model as "contextual, limited, and provisional," which "eschewed trials to focus ... upon a new institutional mechanism: the truth commission" (p. 78), a depiction similar to that of Minow (1998) and Brahm (2007, see endnote 11 above). It reveals the prominence of the retributive-restorative contrast in the transitional justice literature, along with a restricted understanding of "justice" to refer solely to criminal prosecution. For a refreshing exception to this pattern, see Gunatilleke (2015). ${ }^{17}$ I have a high regard for Menkel-Meadow's scholarship; thus, I was surprised to see a huge array of diverse justice activities merged as one. It is little wonder that those new to the field would be baffled by what RJ is or means. To be fair, Menkel-Meadow also considers challenges to RJ.

${ }^{18}$ Other configurations of meetings are possible: they may not be face-to-face; or they may involve victim- and offender-only meetings, which in time may include the relevant protagonists, their supporters, and others. 
${ }^{19}$ There are other problems in the selective take-up of restorative justice terminology into post-conflict settings (Clamp \& Doak, 2012).

\section{References}

Acorn, A. (2004). Compulsory compassion: A critique of restorative justice. Vancouver, BC: UBC Press.

Backer, D. (2009). Cross-national comparative analysis. In H. van der Merwe, V. Baxter, \& A. Chapman (Eds.) Assessing the impact of transitional justice (pp. 23-89). Washington, DC: United States Institute of Peace Press.

Bazemore, G., \& Walgrave, L. (1999). Restorative juvenile justice: in search of fundamentals and an outline for systemic reform. In G. Bazemore \& L. Walgrave (Eds.), Restorative juvenile justice: Repairing the harm of youth crime (pp. 45-74). Monsey, NY: Criminal Justice Press.

Bottoms, A. (2003). Some sociological reflections on restorative justice. In A. von Hirsch, J. Roberts, A. Bottoms, K. Roach, \& M. Schiff (Eds.), Restorative justice and criminal justice: Competing or reconcilable paradigms? (pp. 77-113). Oxford, England: Hart Publishing.

Brahm, E. (2007). Uncovering the truth: Examining truth commission success and impact. International Studies Perspectives, 8, 16-35. 
Braithwaite, J. (2003). Principles of restorative justice. In A. von Hirsch, J. Roberts, A. Bottoms, K. Roach, \& M. Schiff (Eds.), Restorative justice and criminal justice: Competing or reconcilable paradigms? (pp. 1-20). Oxford, England: Hart Publishing.

Braithwaite, J., \& Daly, K. (1994). Masculinities, violence and communitarian control. In T. Newburn \& E. Stanko (Eds.), Just boys doing business? (pp. 189-213). New York: Routledge.

Clamp, K., \& Doak, J. (2012). More than words: restorative justice concepts in transitional justice settings. International Criminal Law Review, 12(3), 339-360.

Coates, R., Umbreit, M., \& Vos, B. (2006). Responding to hate crimes through restorative justice dialogues. Contemporary Justice Review, 9(1), 7-21.

Cook, K., Daly, K., \& Stubbs, J. (Eds.) (2006). Gender, race, and restorative justice [Special Issue]. Theoretical Criminology, 10 (1).

Daly, K. (1989). Criminal justice ideologies and practices in different voices: some feminist questions about justice. International Journal of the Sociology of Law, 17(1), 1-18.

Daly, K. (1992, May). What would have been justice? Sexual harassment in the Thomas hearings [Plenary presentation], Law \& Society Annual Meeting. Philadelphia, PA Available at https://www.griffith.edu.au/_data/assets/pdf_file/0003/50268/kdaly_what_would_ha ve_been_justice.pdf 
Daly, K. (2000). Revisiting the relationship between retributive and restorative justice. In H. Strang \& J. Braithwaite (Eds.), Restorative justice: philosophy to practice (pp. 33-54). Aldershot, England: Ashgate Publishing Company.

Daly, K. (2002a). Sexual assault and restorative justice. In H. Strang \& J. Braithwaite (Eds.), Restorative justice and family violence (pp. 62-88). Cambridge, England: Cambridge University Press.

Daly, K. (2002b). Restorative justice: The real story. Punishment and Society, 4(1), 55-79.

Daly, K. (2006). The limits of restorative justice. In D. Sullivan \& L. Tifft (Eds.), Handbook of restorative justice: A global perspective (pp. 134-145). New York: Routledge.

Daly, K. (2011). Conventional and innovative justice responses to sexual violence. ACSSA (Australian Centre for the Study of Sexual Assault) Issues 12. Melbourne: Australian Institute of Family Studies.

Daly, K. (2014). Reconceptualizing sexual victimisation and justice. In I. VanFraechem, A. Pemberton, \& F. Ndahinda (Eds.), Justice for victims: Perspectives on rights, transition and reconciliation (pp. 378-395). London, England: Routledge.

Daly, K., \& Immarigeon, R. (1998). The past, present, and future of restorative justice: some critical reflections. Contemporary Justice Review 1(1), 21-45. 
Daly, K., \& Marchetti, E. (2012). Innovative justice processes: restorative justice, Indigenous justice, and therapeutic jurisprudence. In M. Marmo, W. de Lint, \& D. Palmer (Eds.), Crime and justice: A guide to criminology (4th ed.) (pp. 455-481). Sydney, Australia: Lawbook Company.

Daly, K., \& Proietti-Scifoni, G. (2009). Defendants in the circle: Nowra Circle Court, the presence and impact of Elders and re-offending. Brisbane, Australia: School of Criminology and Criminal Justice, Griffith University. Available at https://www.griffith.edu.au/_data/assets/pdf_file/0007/189862/Defendants-in-theCircle-updated-Aug-2015.pdf

Daly, K., \& Proietti-Scifoni, G. (2011). Reparation and restoration. In M. Tonry (Ed.), Oxford handbook of crime and criminal justice (pp. 207-253). New York: Oxford University Press.

Daly K., \& Wade, D. (2016). Sibling sexual violence and victims' justice interests: a comparison of youth conferencing and judicial sentencing. In E. Zinsstag \& M. Keenan (Eds.), Sexual violence and restorative justice: legal, social and therapeutic dimensions (working title). London, England: Routledge.

Doak, J., \& O’Mahony, D. (2011). Mediation and restorative justice. In F. Dünkel, J. Grzywa, P. Horsfield, \& I. Pruin (Eds.), Juvenile justice systems in Europe: Current situation and reform developments, (2nd ed.) (pp. 547-621). Mönchengladbach, Germany: Forum Verlag. 
Dünkel, F., Horsfield, P., \& Păroşanu, A. (2015a). Introduction. In F. Dünkel, P. Horsfield, \& A. Păroşanu (Eds.), European research on restorative juvenile justice, Vol. 1, Research and selection of the most effective juvenile restorative justice practices in Europe: Snapshots from 28 EU member states (pp. 1-17). Brussels, Belgium: International Juvenile Justice Observatory.

Dünkel, F., Grzywa-Holten, J., Horsfield, P., \& Păroşanu, A. (2015b). Restorative justice and juvenile offenders in Europe: Comparative overview. In F. Dünkel, P. Horsfield, \& A. Păroşanu (Eds.), European research on restorative juvenile justice, Vol. 1, Research and selection of the most effective juvenile restorative justice practices in Europe: Snapshots from 28 EU member states (pp. 175-251). Brussels, Belgium: International Juvenile Justice Observatory.

Gallie, W. B. (1956). Essentially contested concepts. Proceedings of the Aristotelian Society, 56(1956), 168-198.

Gunatilleke, G. (2015). Confronting the complexity of loss: Perspectives on truth, memory \& justice in Sri Lanka. Colombo, Sri Lanka: Law \& Society Trust.

Hayner, P. (2011). Unspeakable truths: Transitional justice and the challenge of truth commissions (2nd ed.). New York: Routledge.

Johnstone, G. (2008). The agendas of the restorative justice movement. In H. Miller (Ed.), Restorative justice: From theory to practice (pp. 59-79). Bingley, England: Emerald Group. 
Johnstone, G. (2011). Restorative justice: Ideas, values, debates ( $2^{\text {nd }}$ ed.). New York: Routledge.

Johnstone, G., \& Van Ness, D. (2007). The meaning of restorative justice. In G. Johnstone \& D. Van Ness (Eds.), Handbook of restorative justice (pp. 5-23). Cullompton, England: Willan Publishing.

Jülich, S., Buttle, J., Cummins, C., \& Freeborn, E. (2010). Project Restore: An exploratory study of restorative justice and sexual violence. Auckland, NZ: AUT University.

Fattah, E. (1998). Some reflections on the paradigm of restorative justice and its viability for juvenile justice. In L. Walgrave (Ed.), Restorative justice for juveniles. Potentialities, risks and problems (pp. 389-401). Leuven, Belgium: Leuven University Press.

Livingstone, N., Macdonald, G., \& Carr, N. (2013). Restorative justice conferencing for reducing recidivism in young offenders (aged 7 to 21). Cochrane Database of Systematic Reviews, Issue 2. Art. No.: CD008898. doi: 10.1002/14651858.CD008898.pub2.

McEvoy, K., \& Mika, H. (2002). Restorative justice and the critique of informalism in Northern Ireland. British Journal of Criminology, 42(3), 534-563. 
Menkel-Meadow, C. (2007). Restorative justice: What is it and does it work? Annual Review of Law and Social Science, 3, 161-187.

Marchetti, E., \& Daly, K. (2007). Indigenous sentencing courts: towards a theoretical and jurisprudential model. Sydney Law Review, 29, 415-443.

McCold, P. (2000). Toward a holistic vision of restorative juvenile justice: a reply to the maximalist model. Contemporary Justice Review, 3(4), 357-414.

Minow, M. (1998). Between vengeance and forgiveness. Boston, MA: Beacon Press.

Olsen, T., Payne, L., \& Reiter, A. (2010). Transitional justice in balance. Washington, DC: United States Institute of Peace Press.

O’Mahony, D., \& Doak, J. (2009). Restorative justice and youth justice - Bringing theory and practice closer together in Europe. In J. Junger-Tas \& F. Dünkel (Eds.), Reforming juvenile justice (pp. 165-182). Heidelberg, Germany: Springer.

Porter, E. (2012). Gender-inclusivity in transitional justice strategies: Women in Timor-Leste. In S. Buckley-Zistel \& R. Stanley (Eds.), Gender in transitional justice (pp. 221-240). Basingstoke, England: Palgrave Macmillan.

Pranis, K. (2015, 30 August). Using peacemaking circles in juvenile court, 4/22/15.[Youtube video]. Retrieved from https://www.youtube.com/watch?v=5-cNauUCFA0 
Pratt, J. (2006). Beyond evangelical criminology: The meaning and significance of restorative justice. In I. Aertsen, T. Daems, \& L. Robert (Eds.), Institutionalizing restorative justice (pp. 44-67). Portland, OR: Willan Publishing.

Ptacek, J. (Ed.) (2005). Feminism, restorative justice, and violence against women [Special issue]. Violence against Women, 11(5).

Ptacek, J. (Ed.) (2010). Restorative justice and violence against women. New York: Oxford University Press.

Roche, D. (2007). Retribution and restorative justice. In G. Johnstone \& D. Van Ness (Eds.), Handbook of restorative justice (pp. 75-90). Cullompton, England: Willan Publishing.

Shapland, J. (2014). Implications of growth: Challenges for restorative justice. International Review of Victimology, 20(1), 111-127.

Sherman, L., Strang, H., Angel, C., Woods, D., Barnes, G., Bennett, S., \& Inkpen, N. (2005). Effects of face-to-face restorative justice on victims of crime in four randomized, controlled trials. Journal of Experimental Criminology, 1, 367-395.

Strang, H., \& Braithwaite, J. (Eds.) (2002). Restorative justice and family violence. Cambridge, England: Cambridge University Press.

Strang, H., Sherman, L., Mayo-Wilson, E., Woods, D., \& Ariel, B. (2013). Restorative justice conferencing (RJC) using face-to-face meetings of offenders and victims: Effects on 
offender recidivism and victim satisfaction. A systematic review. Campbell Systematic Reviews 2013:12. doi: 10.4073/csr.2013.12.

Stuart, B. (2001). Guiding principles for peacemaking circles. In G. Bazemore \& M. Schiff (Eds.), Restorative community justice: Repairing harm and transforming communities, (pp. 219-41). Cincinnati, OH: Anderson.

Teitel, R. (2003). Transitional justice genealogy. Harvard Human Rights Journal, 16, 69-94.

Teitel, R. (2008). Editorial note, Transitional justice globalized. The International Journal of Transitional Justice, 2, 1-4.

United Nations General Assembly. (2006). Basic principles and guidelines on the right to a remedy and reparation for victims of gross violations of international human rights law and serious violations of international humanitarian law: Resolution adopted by the General Assembly, 21 March A/RES/60/147. Retrieved from http://www.unhcr.org/refworld/docid/4721cb942.html

Van Ness, D., \& Strong, K. H. (2006). Restoring justice: An introduction to restorative justice (3rd ed.). Cincinnati, OH: Anderson.

Van Ness, D., \& Strong, K. H. (2010). Restoring justice: An introduction to restorative justice (4th ed.). New Providence, NJ: LexisNexis Anderson. 
Walgrave, L. (1995). Restorative justice for juveniles: just a technique or a fully fledged alternative? The Howard Journal, 34, 228-49.

Walgrave, L. (2000). How pure can a maximalist approach to restorative justice remain? Or can a purist model of restorative justice become maximalist? Contemporary Justice Review, 3(4), 415-32.

Walgrave, L. (2004). Has restorative justice appropriately responded to retribution theory and impulses? In H. Zehr \& B. Toews (Eds.), Critical issues in restorative justice. Monsey, NY: Criminal Justice Press.

Weatherburn, D. (2014). Arresting incarceration: Pathways out of Indigenous imprisonment. Canberra, Australia: Aboriginal Studies Press.

Yazzi, R., \& Zion, J. W. (1996). Navajo restorative justice: The law of equality and justice. In B. Galway \& J. Hudson (Eds.), Restorative justice: International perspectives (pp. 14451). Monsey, NY: Criminal Justice Press.

Zehr, H. (1985). Retributive justice, restorative justice. Reprinted in G. Johnstone (Ed.), A restorative justice reader (2003, pp. 69-82). Cullompton, England: Willan Publishing.

Zehr, H. (1990). Changing lenses: A new focus for crime and justice. Scottdale, PA: Herald Press.

Zehr, H. (2002). The little book of restorative justice. Intercourse, PA: Good Books. 